\title{
The Effect of Cystine and Methionine, Added Separately or Together, on the Biological Value of the Proteins of Dried Skim Milk
}

\author{
BY KATHLEEN M. HENRY AND S. K. KON \\ National Institute for Research in Dairying, University of Reading
}

(Received 20 December 195I)

It is now well recognized that cystine and methionine are the limiting amino-acids of milk proteins (see, for example, Mitchell \& Block, 1946; Block \& Mitchell, 1946-7). It is also well known that methionine can be converted into cystine in the animal body but that cystine cannot serve as a source of methionine (Womack, Kemmerer \& Rose, 1937; Beach \& White, r939; Tarver \& Schmidt, 1939; Burroughs, Burroughs \& Mitchell, 1940; Rose \& Wood, I94I; Sahyun, 1949). In fact cystine only stimulates growth if the diet contains some methionine (Womack \& Rose, I94I; Glynn, Himsworth \& Neuberger, 1945).

Working with rats, we have shown in this laboratory (Henry, Kon, Lea \& White, I948) that the addition of $0.2 \%$ cystine to spray-dried or freeze-dried milk increased its biological value, at an $8 \%$ level of protein intake, by some $7 \%$.

In view of the metabolic relationship between cystine and methionine we have now compared the effects of both amino-acids on the biological value of milk proteins when added separately or together to milk.

\section{EXPERIMENTAL}

The biological values and true digestibilities of the proteins were determined, at an $8 \%$ level of protein intake, by the method of Mitchell (Mitchell, I923-4; Mitchell \& Carman, I926). Two experiments were done each with three litters of four young growing rats. In both experiments each rat received each diet in turn according to a Latin-square design. Details of the management and feeding of the rats will be found in our earlier publications (Henry, Kon \& Watson, I937; Henry et al. 1948). In Exp. I milk was supplemented with $0.2 \%$ L-cystine, or $0.4 \%$ DL-methionine, or $0.2 \%$ L-cystine with $0.4 \%$ DL-methionine. In Exp. 2 the supplements were $0.4 \%$ L-cystine, $0.2 \%$ DL-methionine, and $0.2 \%$ each of L-cystine and DL-methionine. The basal diet had the following percentage composition: rice starch 64 , sugar 12 , potato starch 10, margarine fat 10, salts (de Loureiro, 193 I) 4. In the experimental diets the milk samples were added to the basal diet in place of an equal weight of rice starch. Details of the milk, nitrogen and moisture contents of the diets are given in Table $\mathbf{r}$.

\section{RESULTS}

Table 2 gives, with their standard errors, mean biological values and true digestibilities of the proteins of the milk samples tested, and Table 3 gives an analysis of variance of the results. These show that $0.2 \%$ L-cystine (Exp. I) increased the biological value 
Table I. Percentage of dried skim milk, added amino-acids, nitrogen and moisture in the experimental diets

$\begin{array}{lccc}\text { Amino-acid added to spray-dried skim milk, } & \text { Milk in } \\ \text { as percentage of the milk } & \text { diet } & \begin{array}{c}\text { Nitrogen in } \\ \text { diet }\end{array} & \begin{array}{c}\text { Moisture } \\ \text { in diet }\end{array} \\ \text { Exp. } 1 \text { : None } & 23.4 & 1 \cdot 247 & 8 \cdot 94 \\ 0.2 \% \text { L-cystine } & 23 \cdot 0 & 1 \cdot 237 & 8 \cdot 88 \\ 0.4 \% \text { DL-methionine } & 23.1 & 1 \cdot 235 & 8 \cdot 88 \\ 0.2 \% \text { L-cystine and } 0.4 \% \text { DL-methionine } & 23.0 & 1 \cdot 248 & 9 \cdot 10 \\ \text { Exp. } 2: \text { None } & 21 \cdot 8 & 1 \cdot 278 & 8 \cdot 64 \\ 0.4 \% \text { L-cystine } & 21 \cdot 7 & \mathbf{1} \cdot 229 & 8 \cdot 74 \\ 0.2 \% \text { DL-methionine } & 21 \cdot 8 & 1 \cdot 279 & 8.67 \\ 0.2 \% \text { L-cystine and } 0.2 \% \text { DL-methionine } & 21 \cdot 7 & 1 \cdot 236 & 8 \cdot 63\end{array}$

Table 2. Mean results for twelve rats in each experiment for the biological values and true digestibilities of the proteins $\left(N \times 6 \cdot 3^{8}\right)$ of the milks studied

Amino-acid added to the milk

$$
\text { Ex }
$$

S.E. Standard error calculated from analysis of variance (see Table 3 ).

Table 3. Analysis of variance of differences in biological value and true digestibility of the proteins $\left(N \times 6.3^{8}\right)$ of the milks studied in the two experiments

\begin{tabular}{|c|c|c|c|c|c|}
\hline \multirow[b]{2}{*}{ Component: } & \multirow[b]{2}{*}{$\begin{array}{l}\text { Degrees of } \\
\text { freedom }\end{array}$} & \multicolumn{2}{|c|}{$\begin{array}{c}\text { Exp. I } \\
\text { Mean squares }\end{array}$} & \multicolumn{2}{|c|}{$\begin{array}{c}\text { Exp. } 2 \\
\text { Mean squares }\end{array}$} \\
\hline & & $\begin{array}{l}\text { Biological } \\
\text { value }\end{array}$ & $\begin{array}{c}\text { True } \\
\text { digestibility }\end{array}$ & $\begin{array}{l}\text { Biological } \\
\text { value }\end{array}$ & $\begin{array}{c}\text { True } \\
\text { digestibility }\end{array}$ \\
\hline \multirow[t]{2}{*}{$\begin{array}{l}\text { Litters } \\
\text { Diets } \\
\text { Periods } \\
\text { Litters } \times \text { diets } \\
\text { Litters } \times \text { periods } \\
\text { Rats within litters } \\
\text { Error }\end{array}$} & $\begin{array}{r}2 \\
3 \\
3 \\
6 \\
6 \\
9 \\
18\end{array}$ & $\begin{array}{c}3 \cdot 27 \\
224 \cdot 59^{* * * *} \\
438 \cdot 87^{* * *} \\
63 \cdot 36^{*} \\
13 \cdot 76 \\
67 \cdot 32^{*} \\
21 \cdot 68\end{array}$ & $\begin{array}{l}23 \cdot 87^{*} \\
14.1 I^{*} \\
23 \cdot 0 I^{* * *} \\
6 \cdot 99 \\
16 \cdot 04^{*} \\
26 \cdot 3 I^{* *} \\
4 \cdot 37\end{array}$ & $\begin{array}{l}28 \cdot 21 \\
122 \cdot 72^{* * * *} \\
292 \cdot 33^{* * *} \\
\text { II·35 } \\
9 \cdot 13 \\
\text { II } 03 \\
\text { I } 2 \cdot 85\end{array}$ & $\begin{array}{c}5 \cdot 36 \\
0 \cdot 80 \\
26 \cdot 70^{*} \\
3 \cdot 63 \\
7 \cdot 59 \\
5 \cdot 65 \\
6 \cdot 36\end{array}$ \\
\hline & & \multicolumn{4}{|c|}{ Biological value } \\
\hline \multirow[t]{3}{*}{ Conclusions: } & & \multirow{2}{*}{\multicolumn{2}{|c|}{$\begin{array}{c}\text { Cystine }>\text { Control* } \\
\text { Methionine }>\text { Cystine* } \\
\text { Methionine }>\text { Control } \\
\text { Cystine + methionine }> \\
\text { Cystine* } \\
\text { Cystine + Methionine }> \\
\text { Control } \\
* * *\end{array}$}} & \multicolumn{2}{|c|}{ Cystine $>$ Control*** } \\
\hline & & & & \multicolumn{2}{|c|}{$\begin{array}{c}\text { Cystine }+ \text { methionine }> \\
\text { Control*** } \\
\text { Methionine }>\text { Control** }\end{array}$} \\
\hline & & \multicolumn{4}{|c|}{$\begin{array}{c}\text { True di } \\
\text { Cystine }>\text { Control* } \\
\text { ystine + Methionine }> \\
\text { Control* }\end{array}$} \\
\hline
\end{tabular}


of the milk proteins by some $5 \%$, in agreement with our earlier results (Henry et al. I948). The further addition of $0.4 \%$ DL-methionine raised the biological value by another $5 \%$; methionine alone had the same effect as the combination of cystine and methionine. Exp. 2 showed that $0.2 \%$ DL-methionine was as effective as $0.4 \% \mathrm{~L}$ cystine, the increase in biological value being this time some $7 \%$, a result very similar to that obtained in Exp. I with $0.4 \%$ methionine. The addition of cystine to the milk supplemented with $0.2 \%$ methionine (Exp. 2) failed to increase the biological value. These findings indicate that $0.2 \%$ DL-methionine gives a nearly maximal response at this level of protein intake.

The effects of these amino-acid additions on the true digestibility of the milk proteins are not clear-cut. Thus, in Exp. I, cystine, alone or in combination with methionine, significantly improved the digestibility in agreement with our earlier findings (Henry et al. 1948); but in Exp. 2 neither cystine nor methionine, separately or together, caused any increase in the true digestibility.

\section{DISCUSSION}

It has not always been recognized that milk is deficient in the sulphur amino-acids. Thus Fairbanks \& Mitchell (1935) considered that the deficiency of cystine observed by them in samples of spray-dried milk was not inherent, but due to destruction of this acid during drying. However, the development of microbiological and other methods for the measurement of amino-acids and the resulting more precise information about the amino-acid composition of different proteins enabled Mitchell and Block (Mitchell \& Block, 1946; Block \& Mitchell, 1946-7) to calculate that, compared with the proteins of whole egg, which are almost completely utilized by the rat, milk proteins are deficient in both cystine and methionine. Moreover, tests in this laboratory showed that the proteins of freshly prepared spray-dried skim milk had the same biological value as those of freeze-dried milk and that both benefited to the same extent from the addition of cystine (Henry et al. 1948), thus indicating that normal heat treatment during processing causes no destruction of cystine.

As methionine can replace cystine it would be expected that with proteins short in both, the former would be the more effective supplement. With small additions, experimental evidence points that way. Thus in the present experiments methionine as $0.2 \%$ of the milk solids proved better than $0.2 \%$ cystine and equal to $0.4 \%$ cystine. With casein Kik (1938) found that the biological value determined at a $9 \%$ protein level was improved to a greater extent by the daily addition of $25 \mathrm{mg}$ methionine than by the same amount of cystine. He estimated that, in this way, the methionine or cystine content of the diet was increased by about $0.25 \%$. This differentiation between cystine and methionine was also found with milk at a slightly lower level of intake (see below).

This superiority of methionine over cystine is not evident from experiments where the rat-growth technique of Osborne, Mendel \& Ferry (1919) was used, probably because in the growth tests the amino-acids were added at higher levels resulting in final dietary concentrations some three to eight times those used by us. Thus Block (1949) found $0.3 \%$ cystine and $0.4 \%$ methionine equally effective as supplements to 
a diet containing $30 \%$ whole dried milk and supplying $7.5 \%$ protein. Both supplements were superior to an additional $10 \%$ milk in the diet, which with it contained I0 $\%$ protein. This result might have been anticipated since it can be calculated that the additional milk would only add some $0.025 \%$ cystine and $0.085 \%$ methionine to the diet, amounts very much less than the amino-acid supplements themselves.

Riesen, Schweigert \& Elvehjem(r946) added $0.2 \%$ L-cystine or $0.4 \%$ DL-methionine, or both, to diets containing 8, I 8 or $50 \%$ casein. The acids, whether added separately or together, improved the growth rate of rats to an equal extent with the $8 \%$ casein diet but did not improve growth with the diets containing the higher proportions of casein. In fact, the simultaneous addition of these acids to the $50 \%$ casein diet resulted in a decrease in growth rate, probably because of an amino-acid imbalance.

Lewis \& Fajans (195I) found cystine and methionine, added separately or together, equally effective supplements to a diet containing $7.5 \%$ casein. The additions were at the relatively high rate of $0.5-0.6 \%$ of the diet.

The dried-milk diets used in the present experiments contained some $0.22 \%$ methionine and $0.05 \%$ cystine (Henry et al. I948). Our additions of 0.2 and $0.4 \%$ cystine or methionine to the milk would increase the concentration of these acids in the diet by some 0.05 or $0.10 \%$. The latest estimate from Rose's laboratory (Wretlind \& Rose, $195^{\circ}$ ) of the minimum methionine requirement for normal growth of the rat in the presence in the diet of all other factors, including $0.2 \%$ cystine, is $0.3-0.4 \%$. Even with the addition of $0.4 \%$ DL-methionine to the milk the total content of methionine of our diet barely reached Wretlind \& Rose's (I950) minimum; moreover, even with the addition of $0.2 \%$ cystine to the milk, the cystine only amounted to about half that in the experiments from which the methionine minimum was derived. A similar estimate of requirements can be reached using Mitchell and Block's (Mitchell \& Block, 1946; Block \& Mitchell, 1946-7) method in which whole-egg protein is taken as the standard. It must be pointed out, however, that our rats were not growing normally on the restricted intake of $8 \%$ protein in the diet and their requirement may have been below Wretlind \& Rose's (1950) minimum. In fact our results would suggest that, at this low level of protein intake, the minimum requirements are covered by the presence in the diet of some $0.27 \%$ methionine and $0.05 \%$ cystine or $0.22 \%$ methionine and $0.15 \%$ cystine, as at these levels the biological value of milk proteins was raised almost to the level of that of whole-egg proteins.

These estimates are based on the assumption that both isomers of methionine are equally well utilized by the rat for growth. Experimental evidence for this has been put forward by Jackson \& Block (I937-8), Rose (1938) and Wretlind \& Rose (1950), though under certain conditions (Bennett, 1939; Nasset \& Anderson, 195I; Van Pilsum \& Berg, I950; Wretlind \& Rose, r950) the unnatural isomer may be less well utilized than the natural.

\section{SUMMARY}

I. In two experiments cystine and methionine were added separately or together to dried skim milk. The effect of these additions on the biological value and true digestibility of the milk proteins was determined on rats at an $8 \%$ level of protein intake. 
2. The biological value of the proteins was improved significantly and to the same extent by the addition to the milk solids of $0.2 \%$ DL-methionine or $0.4 \%$ L-cystine. No further improvement occurred with $0.4 \%$ DL-methionine or when cystine and methionine were given together; $0.2 \%$ L-cystine alone was less effective.

3. In these experiments the sulphur amino-acid requirements of rats growing at a restricted rate because of a limited intake of protein were apparently satisfied by some $0.27 \%$ methionine and $0.05 \%$ cystine or $0.22 \%$ methionine and $0.15 \%$ cystine in the diet.

4. The true digestibility of the milk proteins was not affected by additions of cystine, methionine or both except in the first experiment when cystine caused a small but statistically significant improvement.

Our thanks are due to Miss M. V. Chapman for help with feeding the rats and to Miss V. Glover and Miss M. R. Cooling for help with the nitrogen analyses.

\section{REFERENCES}

Beach, E. F. \& White, A. (1939). F. biol. Chem. 127, 87.

Bennett, M. A. (1939). Biochem. F. 33, 885 .

Block, R. J. (1949). F. Amer. diet. Ass. 25, 937.

Block, R. J. \& Mitchell, H. H. (1946-7). Nutr. Abstr. Rev. 16, 249.

Burroughs, E. W., Burroughs, H. S. \& Mitchell, H. H. (1940). F. Nutr. r9, 363.

de Loureiro, A. (193 I). Arch. Pat., Lisboa, 3, 72.

Fairbanks, B. W. \& Mitchell, H. H. (I935). F. agric. Res. 51, r 107.

Glynn, L. E., Himsworth, H. E. \& Neuberger, A. (1945). Brit. F. exp. Path. 26, 326.

Henry, K. M., Kon, S. K., Lea, C. H. \& White, J. C. D. (1948). F. Dairy Res, 15, 292.

Henry, K. M., Kon, S. K. \& Watson, M. B. (1937). Milk and Nutrition, Part I, p. 37. Reading: National Institute for Research in Dairying.

Jackson, R. W. \& Block, R. J. (I937-8). F. biol. Chem. 122, 425 .

Kik, M. C. (1938). Proc. Soc. exp. Biol., N.Y., 39, 304.

Lewis, H. B. \& Fajans, R. S. (1951). F. Nutr. 44, 399.

Mitchell, H. H. (1923-4). F. biol. Chem. 58, 873.

Mitchell, H. H. \& Block, R. J. (I946). F. biol. Chem. 163, 599.

Mitchell, H. H. \& Carman, G. G. (1926). F. biol. Chem. 68, 183.

Nasset, E. S. \& Anderson, J. T. (I95 I). F. Nutr. 44, 237.

Osborne, T. B., Mendel, L. B. \& Ferry, E. L. (1919). F. biol. Chem. 37, 223.

Riesen, W. H., Schweigert, B. S. \& Elvehjem, C. A. (1946). Arch. Biochem. ro, 387.

Rose, W. C. (1938). Physiol. Rev. 18, 109.

Rose, W. C. \& Wood, T. R. (I94I). F. biol. Chem. 14r, 38r.

Sahyun, M. (1949). Tex. Rep. Biol. Med. 7, 137.

Tarver, H. \& Schmidt, C. L. A. (1939). F. biol. Chem. x30, 67.

Van Pilsum, J. F. \& Berg, C. P. (1950). F. biol. Chem. 183, 279.

Womack, M., Kemmerer, K. S. \& Rose, W. C. (1937). F. biol. Chem. 121, 403.

Womack, M. \& Rose, W. C. (1941). F. biol. Chem. 141, 375.

Wretlind, K. A. J. \& Rose, W. C. (1950). F. biol. Chem. 187, 697. 